\title{
Pengaruh Kualitas Pelayanan Pegawai Administrasi Akademik Terhadap Kepuasan Mahasiswa
}

\author{
Rahmat Yuliawan \\ Universitas Airlangga \\ Korespondensi: rahmat.yuliawan@vokasi.unair.ac.id
}

Diserahkan: 15 Juli 2017, Direvisis: 31 Agustus 2017 Diterima: 5 September 2017

\begin{abstract}
This study aims to determine the effect of service quality administration administration academic to the satisfaction of D3 secretarial management students and offices of Airlangga University involving 129 students as respondents. This type of research uses a quantitative approach. Data were obtained by using questionnaires containing questions with closed answer option using Likert scale. The analytical methods used are F-test, Ttest, determination test, multiple linear regression, validity test and reliability. The results showed that the quality of service consisting of the variable of reliability), Responsive, confidence, empathy, form together have an influence on student satisfaction D3 Secretarial Management and Office Airlangga University. Of the five variables that affect student satisfactionD3 Secretarial Management and Office of Airlanggam University found that belief has the most dominant influence on student satisfaction of D3 Secretariat Management and Airlangga University Office when compared with other variables.

Keywords: Reliability, Renponsiveness, Confidence, Empathy, Being, Satisfaction
\end{abstract}

\begin{abstract}
Abstrak
Penelitian ini bertujuan untuk mengetahui pengaruh kualitas pelayanan administrasi pegawai administrasi akademik terhadap kepuasan mahasiswa D3 manajemen kesekretariatan dan perkantoran Universitas Airlangga dengan melibatkan 129 mahasiswa sebagai responden. Jenis penelitian menggunakan pendekatan kuantitatif. Data diperoleh dengan menggunakan kuisioner yang berisi pertanyaan-pertanyaan dengan opsi jawaban tertutup dengan menggunakan skala likert. Metode analisis yang digunakan adalah uji - F, uji - T, uji determinasi,ujiregresi linear berganda, uji validitas dan reliability. Hasil penelitian menunjukkan bahwa kualitas pelayanan yang terdiri dari variabel kehandalan, Responsif, keyakinan, empati, wujud, secara bersama - sama memiliki pengaruh terhadap kepuasan mahasiswa D3 Manajemen Kesekretariatan dan Perkantoran Universitas Airlangga. Dari lima variabel yang mempengaruhi kepuasan mahasiswaD3 Manajemen Kesekretariatan dan Perkantoran Universitas Airlanggam ditemukan bahwa Keyakinan memiliki penggaruh yang paling dominan terhadap kepuasan mahasiswa D3 Manajemen Kesekretariatan dan Perkantoran Universitas Airlangga jika dibandingkan dengan variabel yang lain.
\end{abstract}

Kata kunci : Kehandalan, Renponsif, Keyakinan, Empati, Wujud, Kepuasan

\section{A. PENDAHULUAN}

Universitas Airlangga merupakan salah satu dari 10 Universitas terbaik di Indonesia (Naibaho, 2007) dan bahkan menjadi salah satu yang menjadi acuan dan contoh bagi universitas lain di wilayah timur Indonesia. Kondisi ini menjadikan Universitas Airlangga terus mengembangkan potensi yang dimilikanya untuk lebih baik lagi. Target masuk peringkat 500 universitas terbaik dunia juga menjadi sesuatu yang mutlak dan harus diraih agar dapat menjadi universitas terbaik bukan hanya di tingkat lokal akan tetapi di tingkat global.

Salah satu indikator keberhasilan sebuah perguruan tinggi di berbagai aspek adalah dilihat dari mahasiswa dan lulusan, dimana keberadaan mereka dirasa sangat penting dan merupakan salah satu asset utama sebuah perguruan tinggi. Tidak mengherankan jika banyak biaya yang akhirnya harus dikeluarkan untuk melakukan 
promosi dan lainya untuk mendapatkan input mahasiswa berkualitas. mahasiswa akan merasa tidak puas jika suatu produk atau jasa tidak sesuai harapan, mahasiswa sebagai pelanggan akan merasa puas jika suatu produk atau jasa sesuai harapan, dan pelanggan akan merasa sangat puas jika suatu produk atau jasa melebihi harapan (Tjiptono, 2001:102). Kepuasan merupakan hal yang bersifat individual karena setiap individu akan memiliki tingkat kepuasan yang berbeda-beda sesuai dengan nilai-nilai yang berlaku dalam diri setiap individu (Ariani, 2015)

Pemasaran kampus baik negeri maupun swasta dewasa ini sangat kreatif dan semua memberikan pelayanan terbaiknya. Oleh karena itu, setiap Universitas melalui unit nya di Fakultas dan Program Studi senantiasa berusaha untuk dapat meningkatkan kepuasan mahasiswa sehingga dia akan menceritakan yang baik dan menjadi exposure positif secara tidak langsung bagi sebuah lembaga. Program Studi menjadi ujung tombak sebuah lembaga pendidikan yang harus dapat menterjemahkan strategi pemasaran Universitas sehingga dapat bertahan dan memenangi persaingan dengan Universitas lain. Hal ini tentu saja harus mendapatkan dukungan dari semua lini di Fakultas maupun Program Studi.

Fakultas vokasi adalah merupakan Fakultas paling muda di Universitas Airlangga.Perbaikan di berbagai bidang kemudian menjadi hal yang utama, termasuk dalam perbaikan pelayanan. Dalam struktur organisasi Ketua program studi merupakan ujung tombak dari pengembangan program studi (prodi) tersebut, dan yang tidak kalah pentingnya adalah peran dari seorang petugas admnistrasi akademik yang disingkat dengan PAA.

PAA merupakan seseorang petugas yang langsung berhadapan dengan mahasiswa terutama terkait dengan pelayanan administrasi dan akademik.Sehingga pelayanan merupakan sebuah hal yang harus dimiliki.Setiap program studi memiliki seorang petugas administrasi akademik (PAA) yang bekerja menyelesaiakan permasalahan administrasi dan akademik.

Program studi manajemen kesekretariatan dan perkantoran merupakan salah satu program studi yang ada di Fakultas Vokasi Universitas Airlangga. Dari sisi administrasi dan pelayanan seharusnya dapat menjadi percontohan bagi program studi yang lain mengenai pelayanan. Akan tetapi Fenomena yang terjadi saat ini ternyata masih adanya mahasiswa yang memiliki beberapa keluhan terkait pelayanan PAA di beberapa program studi, baik itu mengenai terbatasnya informasi yang diberikan oleh PAA kepada mahasiswa maupun pelayanan yang masih dirasa tidak cepat tanggap serta sistem administrasi yang dianggap masih lambat (Rofiah dan Wahyuni, 2017).

Pada tataran konsep sebuah kepuasan pelanggan yang dalam hal ini adalah fungsi seberapa dekat harapan konsumen yang dalam hal ini mahasiswa jasa dengan mutu yang dirasakan. Pelanggan akan merasa tidak puas jika suatu produk atau jasa tidak sesuai harapan, pelanggan akan merasa puas jika suatu produk atau jasa sesuai harapan, dan pelanggan akan merasa sangat puas jika suatu produk atau jasa melebihi harapan (Tjiptono, 2001:102).

Mengingat betapa pentingnya peran kualitas pelayanan bagi kehidupan suatu organisasi untuk berupaya meningkatkan potensi yang dimiliki maka Pelayanan terhadap mahasiswa menjadi sangat penting artinya bagi kinerja sebuah prodi termasuk prodi D3 manajemen kesekretariatan dan perkantoran.Maka dari itu, upaya pimpinan yang harus mengetahui hal-hal apa saja yang di anggap penting oleh mahasiswa, pimpinan dan stakeholder berusaha untuk menghasilkan kinerja (peformance) sebaik mungkin sehingga dapat memuaskan pelanggan yang dalam hal ini adalah mahasiswa 
D3 manajemen kesekretariatan dan perkantoran yaitu dengan memperhatikan faktorfaktor pelayanan seperti Kehandalan, responsif, keyakinan, empati, dan wujud dalam kualitas pelayanan yang mempengaruhi kepuasan mahasiswa (Amalia, 2010)

Melihat adanya upaya pimpinan yang terus mengembangkan fakultas vokasi kedepannya termasuk dalam memberikan pelayanan prima oleh PAA kepada mahasiswa untuk menarik kepuasan mahasiswa, maka penulis tertarik untuk meneliti pengaruh kualitas pelayanan yang diberikan PAA terhadap kepuasan mahasiswa D3 Manajemen Kesekretariatan dan Perkantoran .

Impilkasi dan manfaat dari hasil dari penelitian ini diharapkan dapat memperkuat customer satisfaction theory yang akan dijadikan landasan bagi akademisi dan sekaligus menjadi sumber informasi penting bagi lembaga yang dalam hal ini program studi d3 manajemen kesekretariatan dan perkantoran.

Penelitian ini mengangkat beberapa rumusan masalah yaitu: 1) Apakah faktor faktor Kehandalan, Responsif, keyakinan, empati dan wujud yang merupakan dimensi sebuah kualitas berpengaruh terhadap kepuasan mahasiswa D3 Manajemen Kesekretariatan dan Perkantoran, 2) faktor apakah yang paling dominan berpengaruh terhadap kepuasan mahasiswa D3 Manajemen Kesekretariatan dan Perkantoran. Penelitian ini dibatasi pada: 1) Subjek penelitian adalah mahasiswa D3 Manajemen Kesekretariatan dan Perkantoran Fakultas Vokasi Universitas Airlangga, 2) Semua mahasiswa yang terlibat sebagai subjek penelitian wajib mengisi kuesioner dengan kreteria khusus hanya dilakukan kepada mahasiswa yang pernah berhubungan secara langsung dengan petugas administrasi dan akademik (PAA) D3 Manajemen Kesekretariatan dan Perkantoran.

\section{B. LANDASAN TEORI Pengertian Kualitas}

Menurut definisi American Socienty for quality control dalam buku Kothler 2008 : 143 mengatakan kualitas (quality) adalah totalitas fitur dan karakteristik produk atau jasa yang bergantung pada kemampuannya untuk memuaskan kebutuhan yang dinyatakan atau tersirat. Ini jelas merupakan definisi yang berpusat pada pelanggan. Meskipun tidak ada definisi mengenai kualitas yang di terima secara universal dari definisi-definisi yang ada terdapat beberapa kesamaan yaitu dalam elemen - elemen (Tjiptono, 2001:3) yaitu: 1) Kualitas meliputi usaha memenuhui atau melebihi harapan pelanggan, 2) Kualitas mencakup produk, jasa, manusia, proses, dan lingkungan, 3) Kualitas merupakan kondisi yang selalu berubah (misalnya apa yang di anggap merupakan kualitas saat ini mungkin di anggap kurang berkualitas pada masa mendatang). Sedangkan menurut Supranto (2011:228) adalah sebuah kata yang bagi penyedia jasa merupakan sesuatu yang harus dikerjakan dengan baik.

\section{Dimensi Kualitas Jasa}

Berdasarkan model kualitas jasa ini, periset mengendentifikasikan lima determinan kualitas jasa yaitu:

1. Keandalan, yaitu kemampuan untuk melaksanakan jasa yang di janjikan dengan andal dan akurat. Adapun indikator - indikator Keandalan yaitu: a) Menyediakan jasa yang di janjikan, b) Keandalan dalam penangganan masalah layanan pelanggan, c) Melaksanakan jasa dengan benar pada saat pertama, d) Menyediakan jasa pada waktu yang di janjikan, e) Mempertahankan catatan bebas kesalahan, f) Karyawan yang mempunyai pengetahuan untuk menjawab pertanyaa pelanggan 
2. Responsif yaitu kesediaan membantu pelanggan dan memberikan layanan tepat waktu. Adapun indikator - indikator responsif yaitu: a) Selalu memberitahu pelanggan kapan layananan akan dilakasanakan, b) Layanan tepat waktu bagi pelanggan, c) Kesediaan untuk membantu pelanggan, d) Kesediaan untuk merespon permintaan pelanggan

3. Keyakinan yaitu pengetahuan dan kesopanan karyawan serta kemampuan mereka untuk memnunjukkan keperjayaan dan keyakinan. Adapun indikator indikator keyakinan yaitu: a) Karyawan yang menanamkan keyakinan pada pelanggan, b) Membuat pelanggan merasa puas dalam transaksi mereka, c) Karyawan yang selalu sopan

4. Empati yaitu kondisi mempertahatikan dan memberikan perhatian pribadi kepada pelanggan. Adapun indikator - indikator empati yaitu: a) Memberikan perhatian pribadi kepada pelanggan, b) Karyawan yang mengahadapi pelanggan dengan cara yang penuh perhatian, c) Mengutamakan kepentingan terbaik pelanggan, d) Karyawan yang memahami kebutuhan pelanggan mereka, e) Jam bisnis yang nyaman

5. Wujud yaitu penampilan fasilitas fisik, perlalatan personel dan bahan komunikasi. Adapun indikator - indikator wujud yaitu : a) Peralatan modern,b) Fasilitas yang tampak menarik secara visual, c) Karyawan yang memiliki penampilan rapi an professional, d) Bahan yang berhubungan dengan jasa mempunyai daya tarik visual (Kothler, 2008)

\section{Kepuasan pelanggan}

Kothler dalam bukunya manajemen pemasaran jilid 1 2008: 139 mengatakan Kepuasan (satisfaction) adalah perasaan senang atau kecewa seseorang yang timbul karena membandingkan kinerja yang di persepsikan produk atau hasil terhadap ekspektasi mereka.Kepuasan pelanggan merupakan fungsi dari kesan dari kinerja dan harapanya. Sedangkan Wilton (dalam Tjiptono, 2001:102) menyatakan bahwa kepuasan pelanggan adalah respons pelanggan terhadap evaluasi ketidak kesesuaian yang di rasakan antara harapan sebelumnya (atau norma kinerja lainnya) dan kinerja aktual produk yang dirasakan setelah pemakeannya. Wilkie (dalam Tjiptono, 2001:102) mendefinisikannya sebagai suatu tanggapan emosional pada evaluasi terhadap pengalaman konsumsi suatu produk atau jasa. Engel, et al (dalam Tjiptono, 2001:102) menyatakan bahwa kepuasan pelangan merupakan evaluasi purnabeli di mana alternatif yang di pilih sekurang kurangnya sama atau melampaui harapan pelanggan, sedangkan ketidakpuasan timbul apabila hasil (outcome) tidak memenuhui harapan.

Faktor Realibility, responsiveness, assurance,, emphaty, dan tangible terbukti secara pengaruh yang positif terhadap kepusan pelanggan (Bandu danYunus; 2013) yang bermuara pada loyalitas pelanggan (Agustina, 2012). Sedangkan Yamit (2001) menyatakan bahwa agar dapat memuaskan kebutuhan pelanggan, perusahaan dapat melakukan dengan tahapan-tahapan yaitu: a) Mengetahui kebutuhan dan keinginan pelanggan, b) Mengetahui proses pengambilan keputusan dalam membeli, c) Membangun citra perusahaan, d) Membangun kesadaran akan pentingnya kepuasan pelanggan

\section{Hipotesis penelitian}

Berdasarkan rumusan masalah yang ada, penulis menduga bahwa :

1. Faktor - faktor Kehandalan, Responsif, keyakinan, empati dan wujud berpengaruh terhadap kepuasan mahasiswa D3 Manajemen Kesekretariatan dan Perkantoran. 
2. Faktor responsif diduga sebagai faktor paling berengaruh terhadap kepuasan mahasiswa D3 Manajemen Kesekretariatan dan Perkantoran.

\section{METODE PENELITIAN}

\section{Jenis Penelitian, Populasi, Sampel dan Data}

Jenis penelitian menggunakan pendekatan Kuantitatif, dengan populasi seluruh mahasiswa D3 Manajemen Kesekretarian dan Perkantoran Fakultas Vokasi Universitas Airlanggadengan kreteria khusus yaitu mahasiswa yang pernah berhubungan secara langsung dengan petugas administrasi dan akademik (PAA) D3 Manajemen Kesekretariatan dan Perkantoran. Sedangkan yang menjasi sampel sekaligus responden penelitian adalah dari mahasiswa D3 manajemen kesekretariatan dan perkantorandengan karakteristik khusus.Adapun populasi dalam penelitian ini adalah sebesar 129 yang memenuhi kreteria yang telah ditetapkan yaitu pernah berhubungan secara langsug dengan petugas administrasi (PAA) D3 manajemen kesekretariatan dan perkantoran.

Sumber data yang digunakan dalam penelitian ini adalah :

1. Sumber data primer, yaitu informasi yang dikumpulkan langsung dari responden berupa hasil pengisian kuesioner oleh responden. Kuisioner diyang digunakan berisi pertanyaan dengan jawaban tertutup dengan opsi jawaban menggunakan skala likert 5 (lima).

2. Sumber data sekunder, yaitu sumber data kedua setelah sumber data primer, yang dihasilkan dari penelitian terdahulu. Data primer diperoleh melalui studi kepustakaan, yaitu memperoleh literatur dari berbagai media daring dan luring.

\section{Indentifikasi dan Definisi operasional variabel}

Variabel adalah ciri dari induvidu, objek, gejala atau peristiwa yang di ukur secara kuantitatif.Variabel menunjukkan atribut dari sekelompok orang atau objek yang mempunyai variasi antara satu dengan yang lainya dalam kelompok itu (Riduwan , 2009). Berdasarkan hubungan antara satu variabel dengan variabel lain, maka penelitian ini di bedakan menjadi dua macam yaitu :

a. Variabel bebas $(\mathrm{X})$ atau independen adalah variabel yang menjadi sebab perubahan atau timbulnya variabel dependen (terikat). Variabel bebas dalam penelitian ini adalah Keandalan $\left(\mathrm{X}_{1}\right)$, Responsif $\left(\mathrm{X}_{2}\right)$, keyakinan $\left(\mathrm{X}_{3}\right)$, empati $\left(\mathrm{X}_{4}\right)$, dan wujud $\left(\mathrm{X}_{5}\right)$

b. Variabel terikat $(\mathrm{Y})$ atau dependen adalah variabel yang di pengaruhui atau menjadi akibat karena variabel independen (bebas). Adapun varibel terikat dalam penelitian ini adalah kepuasan pelanggan $(\mathrm{Y})$

Definisi operasional di maksudkan untuk menjelaskan dan mengukur makna variabel yang sedang di teliti (Ariani, 2015). Pada peneltian ini, defini operasional variabel yang dimaksud adalah;

1. Kepuasan mahasiswa adalah hasil (outcome) yang dirasakan atas penggunaan produk dan jasa, sama atau melebihi harapan yang diinginkan. Indikator kepuasan adalah terpenuhinya harapan, keinginan dan kebutuhan pelanggan.

2. Kehandalan adalah bentuk pemberian pelayanan yang diberikan kepada mahasiswa oleh PAA D3 manajemen kesekretaritan dan perkantoran sesuai tingkat pemahaman dan tindak lanjut dalam merespon suatu pelayanan yang diterima. Indikatornya adalah pelayanan yang menyenangkan, kecakapan dalam pelayanan, menciptakan respon yang positif.

3. Responsifadalah bentuk pemberian pelayanan yang sesuai dengan komitmen harapan kepuasan pelayanan yang diberikan kepada mahasiswa. Indikatornya adalah 
memperlihatkan sikap ramah/sopan, menjamin keamanan dan keselamatan mahasiswa serta pelayanan yang memuaskan.

4. keyakinan adalah pengetahuan dan kesopanan karyawan serta kemampuan mereka untuk menimbulkan kepercayan dan keyakinan.

5. Empati adalah suatu sikap dan kepedulian dalam memberikan bentuk pelayanan kepada mahasiswa oleh PAA D3 manajemen kesekretaritan dan perkantoran. Indikatornya adalah keseriusan memberikan pelayanan, perhatian dan peduli kepada mahasiswa yang membutuhkan layanan

6. berwujud yaitu penampilan fasilitas fisik perlalatan, personil, dan media komunikasi

\section{Teknik Analisa Data}

Data yang massuk selanjutnya akan dianalisa menggunakan alat bantu SPSS versi 18.0, dengan melalui serangkaian pengujian yaitu: 1) Uji Validitas dan Realiabilitas, 2) Analisis regresi linear berganda, 3) Koefisien determinasi dan 4) Pengujian Hipotesis

Selain itu, juga dilakukan analisa deskriptif. Hal ini bertujuan untuk dapat melihat sebagian besar pengaruh kualitas pelayanan yang diberikan oleh PAA D3 manajemen kesekretariatan dan perkantoran.Adapun dimensi - dimensi kualitas pelayanan yang meliputi Keandalan (X1), responsif (X2), keyakinan (X3), Empati (X4), wujud (X5).

\section{HASIL DAN PEMBAHASAN}

\section{Hasil Analisa Regresi dan Koefisien Determinan}

Untuk melihat sejauh mana pengaruh kualitas pelayanan terhadap kepuasan mahasiswa pada Pegawai PAA D3 Manajemen Kesekretariatan dan Perkantoran Universitas Airlangga, maka selanjutnya di lakukan pengolahan data melalui persaman regresi linier berhganda dengan menggunkan program SPSS 18.0 di mana variabel bebas $(X)$ yakni terdiri dari kehandalan $\left(\mathrm{X}_{1}\right)$, responsive $\left(\mathrm{X}_{2}\right)$, empati $\left(\mathrm{X}_{3}\right)$, keyakinan $\left(\mathrm{X}_{4}\right)$, wujud $\left(\mathrm{X}_{5}\right)$ terhadap variabel terikat kepuasan mahasiswa $(\mathrm{Y})$.

Dari hasil pengolahan data, diperoleh hasil sebagai berikut:

\section{Tabel 1. Nilai Koefisien regresi berganda}

\section{Coefficients $^{\text {a }}$}

\begin{tabular}{|c|c|c|c|c|c|c|}
\hline \multirow[b]{2}{*}{ Model } & & \multicolumn{2}{|c|}{ Unstandardized Coefficients } & \multicolumn{3}{|c|}{$\begin{array}{l}\text { Standardized } \\
\text { Coefficients }\end{array}$} \\
\hline & & $\mathrm{B}$ & Std. Error & Beta & $\mathrm{T}$ & Sig. \\
\hline \multirow[t]{6}{*}{1} & (Constant) & 2.426 & 1.635 & & 1.484 & .140 \\
\hline & Keandalan & -.164 & .102 & -.145 & -1.614 & .109 \\
\hline & Responsif & 617 & .214 & .271 & 2.878 & .005 \\
\hline & Keyakinan & .520 & .091 & .431 & 5.736 & .000 \\
\hline & Empati & .248 & .113 & .248 & 2.198 & .030 \\
\hline & Wujud & -.095 & .095 & -.093 & -.999 & .320 \\
\hline
\end{tabular}

a. Dependent Variable: Kepuasan_mahasiswa

Sumber : Data diolah 2017

Berdasarkan tabel diatas di peroleh hasil perhitunagan regresi linear berganda yaitu:

$\mathrm{Y}=2.426+(-0164) \mathrm{X}_{1}+0.617 \mathrm{X}_{2}+0.520 \mathrm{X}_{3}+0.248 \mathrm{X}_{4}+(-0.095) \mathrm{X}_{5}+1.636$

Dari persamaan diatas, diketahui bahwa variebel independen yang terdiri dari kepuasan mahasiswa yang terdiri dari keandalan, responsif, keyakianan, empati dan wujud mempunyai pengaruh positif dengan peningkatan kepuasan mahasiswa di kemukakan 
nilai contant $\mathrm{a}=2.426$ menunjukkan bahwa semakin meningkatnya pelayanan produk di berikan akan berpengaruh positif terhadap kepuasan mahasiswa yang di rasakan oleh mahasiswa D3 Manajemen Kesekretariatan dan Perkantoran Universitas Airlangga.

Sedangkan hasil dari pengujian keofisiensi determinasi berganda (R-square) diperoleh hasil sebagai berikut:

Tabel 2. Hasil analisis model summary

\begin{tabular}{lllll}
\hline Model R & R Square & Adjusted R Square & Std. Error of the Estimate \\
\hline 1 & $.586^{\mathrm{a}}$ & .343 & .316 & 2.441 \\
\hline
\end{tabular}

a. Predictors: (Constant), Wujud, Keyakinan, Keandalan, Responsif, Empati

Sumber :Data diolah 2017

Pada tabel diatas diketahui bahwa nilai koefisien korelasi (R) sebesar 0.586, nilai koefisien determinasi ( $\mathrm{R}$ Square) sebesar 0.343 (34.3\%). Koefisien determinasi ini menunjukkan bahwa 34.3\% keputusan mahasiswa untuk puas kepada Pegawai PAA D3 Manajemen Kesekretariatan dan Perkantoran Universitas Airlangga dapat dijelaskan atau dipengaruhi oleh keragaman pelayanan, kualitas pelayanan dan kepuasan mahasiswa sedangkan sisanya $(100 \%-34,3 \%=65.7 \%)$ keputusan mahasiswa untuk puas kepada Pegawai PAA D3 Manajemen Kesekretariatan dan Perkantoran Universitas Airlangga dipengaruhi oleh hal-hal atau variabel lain.

Uji Simultan (Uji F)

Uji F merupakan uji secara bersama sama untuk menguji signifikan pengaruh variabel kualitas jasa yang terdiri dari Keandalan, responsif, keyakinan, dan empati dan wujud serta bersama - sama terhadap variabel kepuasan mahasiswa. Dari hasil pengolahan menggunakan SPSS, diperoleh hasil sebagai berikut:

Tabel 3. Analysis Of Variance

\begin{tabular}{lllllll}
\hline \multicolumn{1}{l}{ Model } & & Sum of Squares & Df & Mean Square F & Sig. \\
\hline \hline 1 & Regression & 382.923 & 5 & 76.585 & 12.853 & $.000^{\mathrm{a}}$ \\
& Residual & 732.891 & 123 & 5.958 & & \\
& Total & 1115.814 & 128 & & & \\
\hline
\end{tabular}

a. Predictors: (Constant), Wujud, Keyakinan, Keandalan, Responsif, Empati

b. Dependent Variable: Kepuasan_mahasiswa

Sumber : Data diolah 2017

Berdasarkan tabel diatas diperoleh nilai probabilitas sig. 0,000 Oleh karena probabilitas $(0,000)$ jauh lebih kecil dari 0,05 , maka $\mathrm{H}_{\mathrm{a}}$ diterima $\mathrm{H}_{0}$ ditolak. Maka dapat disimpulkan bahwa kualitas pelayanan memiliki pengaruh yang signifkan terhadap kepuasan mahasiswa.

Uji Parsial (Uji t)

Uji t di lakukan untuk melihat sejauh mana pengaruh secara persial masing masing dengan variabel independen yaitu Keandalan, responsif, keyakinan, empati dan wujud. Uji $t$ di lakukan juga untuk melihat variabel mana yang paling dominan. Uji di lakukan untuk membandingkan thitung lebih besar di bandingkan $t_{\text {tabel }}$ maka dapat di simpulkan bahwa variabel tersebut memiliki pengaruh signifikan atau sebaliknya berdasarkan hasil perhitungan regresi yang di lakukan maka di peroleh kofisien parsial dari masing - masing variabel independen sebagaimana hipotesis. Dari hasil pengolahan 
data sebagaimana yang tampak pada tabel 1 (satu), dapat disimpulkan beberapa hal yaitu:

\section{Pengaruh kehandalan terhadap kepuasan mahasiswa}

Dari hasil penelitian diketahui bahwa untuk variabel Kehandalan (X1), diperoleh nilai $\mathrm{t}_{\text {Hitung }}<\mathrm{t}_{\text {tabel }}(-1.614<1.978)$ maka $\mathrm{H}_{0}$ di terima $\mathrm{Ha}$ di tolak ini berarti variabel Kehandalan berpengaruh tidak signifikan terhadap kepuasan mahasiswa. Hal ini dapat disimpulkan bahwa mahasiswa sudah puas terhadap kemampuan memberikan pelayanan yang di janjikan (kehandalan). Kemudian dengan masih adanya jawaban responden kurang setuju berarti perusahaan masih perlu melakukan perbaikan terhdap pelayanan dalam segi kehandalan untuk di masa yang akan datang agar mahasiswa puas terhadap pelayanan yang diberikan. Hubungan kehandalan dengan kepuasan mahasiswa adalah kehandalan mempunyai pengaruh positif terhadap kepuasan mahasiswa. Semakin baik persepsi mahasiswa terhadap kehandalan maka kepuasan mahasiswa juga akan semakin tinggi. Jika persepsi mahasiswa terhadap keandalan buruk maka kepuasan mahasiswa juga akan semakin rendah. Hal ini sesuai dengan pendapat Zethami (2004) yang menyatakan responsif merupakan suatu hal yang secara nyata turut mempengaruhui kepuasan mahasiswa untuk menggunakan jasa yang di tawarkan.

\section{Pengaruh responsif terhadap kepuasan mahasiswa}

Dari hasil penelitian diketahui bahwa untuk variabel reponsif (X2), diperoleh nilai $t_{\text {hitung }}>t_{\text {tabel }}(2.878>1.978)$ maka $h 0$ di tolak ha di terima. Ini berarti variabel Responsif berpengaruh signifikan terhadap kepuasan mahasiswa. Dari hasil pengamatan/ analisa deskriptif, masih banyak responden yang menjawab setuju dan kurang setuju, ini berarti tingkat responsif dari PAA D3 manajemen kesekretariatan dan perkantoran masih perlu di tingkatkan khususnya sikap PAA D3 manajemen kesekretariatan dan perkantoran dalam melayani, respon permintaan oleh mahasiswa dan selalu memiliki waktu luang membantu mahasiswa dalam memenuhui kebutuhannya. Namun demikian, sebagian besar responden menyatakan bahwa PAA D3 telah responsif dan cukup peduli terhadap mereka. Hubungan Responsif dengan kepuasan mahasiswa adalah responsive mempunyai pengaruh positif terhadap kepuasan mahasiswa. Semakin baik persepsi mahasiswa terhadap responsif maka kepuasan mahasiswa juga akan semakin tinggi. Jika persepsi mahasiswa terhadap responsif buruk maka kepuasan mahasiswa juga akan semakin rendah. Hal ini sesuai dengan pendapat Zeithami (2004) yang menyatakan keyakinan merupakan suatu hal secara nyata turut mempengruhi kepuasan mahasiswa untuk kembali menggunakan jasa yang di tawarkan

\section{Pengaruh keyakinan terhadap kepuasan mahasiswa}

Dari hasil penelitian diketahui bahwa untuk variabel keyakinan (X3), diperoleh nilai $t_{\text {Hitung }}>t_{\text {Tabel }}(5,736>1.978)$ maka $\mathrm{h} 0$ di tolak ha di terima. Ini berarti variabel keyakinan berpengaruh signifikan terhadap kepuasan mahasiswa.

Dari hasil analisa deskriptif terhadap jawaban responden diketahui bahwa mahasiswa cukup puas terhadap pengetahuan, kemampuan, keramahan, sopan, dan sifat dapat di percaya. Kemudian dengan masih adanya jawaban responden sangat tidak setuju, berarti PAA D3 manajemen kesekretariatan dan perkantoran masih perlu melakukan perbaikan terhadap pelayanan dalam segi keyakinan untuk di masa yang akan datang agar mahasiswa puas terhadap pelayanan yang di berikan. Pelayanan yang di berikan sangat mempengaruhui citra dan persepsi mahasiswa terhadap PAA D3 manajemen kesekretariatan dan perkantoran.Agar dapat memberikan pelayanan yang baik, PAA D3 manajemen kesekretariatan dan perkantoran tidak hanya di tuntut untuk memiliki wawasan dan kemampuan yang baik, tetapi juga harus bersikap ramah, sopan 
dan bernampilan rapi dan melayani mahasiwa.Penilaian atribut keramahan, kesopanan, dan kerapihan, petugas ditentukan oleh tingakt kepentingan dan tingkat kepuasan relative dari mahasiswa.Hasil Atribut keramaahan, kesopanan, dan kerapihan PAA D3 manajemen kesekretariatan dan perkantoran. Sebagian besar mahasiswa mengangap atribut ini sangat penting untuk di perhatikan pihak PAA D3 manajemen kesekretariatan dan perkantoran karena dengan keramahan, kesopanan, PAA D3 manajemen kesekretariatan dan perkantoran mahasiswa akan merasa nyaman untuk melakukan konsultasi dan mencari informasi yang dibutuhkan, maka mereka akan puas merasa di hormati dan di hargai.Hal ini sesuai dengan pendapat Zeithami (2004) yang menyatakan empati merupakan suatu hal secara nyata turut mempenagruhui kepuasan untuk membeli dan menggunakan jasa yang di tawarkan.

\section{Pengaruh empati terhadap kepuasan mahasiswa}

Dari hasil penelitian diketahui bahwa untuk variabel empati $\left(\mathrm{X}_{4}\right)$, diperoleh nilai $\mathrm{t}_{\text {Hitung }}>\mathrm{t}_{\text {Tabel }}(2.198>1,979)$ maka h0 di tolak ha di terima. Ini berarti variabel empati berpengaruh signifikan terhadap kepuasan mahasiswa. Mahasiswa sudah cukup puas terhadap empati yang di berikan kepada mereka. Kemudian dengan masih adanya seberapa jawaban responden sagat tidak setuju, berarti PAA D3 manajemen kesekretariatan dan perkantoran masih perlu melakukan perbaikan terhadap pelayanan dalam segi empaty untuk di masa yang akan datang agar mahasiswa puas terhadap pelayanan yang di berikan. Hubungan empati dengan kepuasan mahasiswa adalah empati mempunyai pengaruh positif terhadap kepuasan mahasiswa. Semakin baik persepsi mahasiswa terhadap empati maka kepuasan juga akan semakin tinggi. Jika persepsi mahasiswa terhadap empati buruk maka kepuasan mahasiswa juga akan semakin rendah. Hal ini sesuai dengan pendapat Zeithami dan bitner ( 2004) yang menyatakan wujud merupakan suatu hal yang secara nyata turut mempengaruhui kepuasan untuk menggunakn jasa yang ditawarkan.

\section{Pengaruh wujud terhadap kepusan mahasiswa}

Dari hasil penelitian diketahui bahwa untuk variabel wujud $\left(\mathrm{X}_{1}\right)$, diperoleh nilai $\mathrm{t}_{\text {Hitung }}<\mathrm{t}_{\text {Tabel }}(-0.999<1.979)$ maka h0 di terima ha di tolak . Ini berarti variabel wujud tidak berpengaruh signifikan terhadap kepuasan mahasiswa.

Dari hasil analisis deskriptif juga diketahui bahwa mahasiswa sudah cukup puas terhadap wujud yang disediakan oleh PAA D3 manajemen kesekretariatan dan perkantoran. Kemudian dengan masih adanya seberapa jawaban responden yang tidak stuju berarti PAA D3 manajemen kesekretariatan dan perkantoran masih perlu melakukan perbaikan terhadap pelayanan dalam segi wujud untuk di masa yang akan datang agar mahasiswa puas terhadap pelayanan yang di berikan.Hubungan bukti fisik dengan kepuasan mahasiswa adalah bukti fisik mempunyai pengaruh positif terhadap kepuasan mahasiswa. Semakin baik persepsi mahasiswa terhadap wujud maka kepuasan mahasiswa juga akan semakin tinggi. Jika persepsi mahasiswa terhadap wujud buruk maka kepuasan mahasiswa juga akan semakin rendah.

\section{Kepuasan Pelanggan}

Dari hasil analisa deskriptif, diketahui bahwa sebagian besar responden cukup puas dengan pelayanan yang diberikan PAA D3. Ini berarti bahwa penerapan kualitas pelayanan oleh PAA D3 Manajemen Kesekretariatan dan Perkantoran kepada pelanggan masih perlu ditingkatkan agar seluruh pelanggan dapat merasakan pelayanan yang memuaskan. Hal ini disebabkan pelayanan yang yang di berikan PAA D3 Manajemen Kesekretariatan dan Perkantoran belum maksimal, sehingga terjadi kesenjangan sehingga ada mahasiswa yang kurang puas dan ada yang puas, atau dengan 
kata lain terkadang PAA D3 Manajemen Kesekretariatan dan Perkantoran masih memberikan pelayanan yang diskriminatif kepada mahasiswa.

\section{E. PENUTUP}

Berdasarkan hasil penelitian dan pembahasan yang telah di jelaskan bahwa hasil yang di peroleh dari faktor-faktor kualitas pelayanan yaitu kehandalan, responsif, keyakinan, empati, dan wujud berpengaruh signifikan dalam menunjang atau memberikan kepuasan pada mahasiswa. Secara parsial faktor faktor kualitas pelayanan yaitu Responsif, keyakinan, dan empati juga berpengaruh signifikan terhadap kepuasan mahasiswa. Sedangkan faktor faktor kualitas pelayanan yaitu kehandalan dan wujud berpengaruh tidak signifikan terhadap kepuasan mahasiswa. Dari hasil penelitian juga diperoleh bahwa variabel keyakinan merupakan variabel yang mempunyai pengaruh yang paling dominan terhadap kepuasan mahasiswa.

Maka dari simpulan diatas, disarankan kepada pihak PAA D3 Manajemen Kesekretariatan dan Perkantoran agar terus meningkatkan kualitas layanan kepada konsumen, dalam hal ini adalah mahasiswa Manajemen Kesekretariatan dan Perkantoran Universitas Airlangga.

\section{DAFTAR PUSTAKA}

Agustina, V., \& Yoestini, Y. (2012). Analisis Pengaruh Kualitas Pelayanan, Kepuasan Pelanggan, dan Nilai Pelanggan Dalam Meningkatkan Loyalitas Pelanggan Joglosemar Bus (Studi Pada Wilayah Semarang Town Office) (Doctoral dissertation, Fakultas Ekonomika dan Bisnis).

Amalia, C. H. (2010). Hubungan antara Kepuasan Konsumen dan Kualitas Pelayanan dengan Loyalitas Konsumen pada Ritel Modern (Doctoral dissertation, Universitas Sebelas Maret).

Ariani, L. (2015, Nopember). Analisis Faktor-Faktor Kepuasan Karyawan PT OSI Electronics Display Batam. Eksis: Jurnal Riset Ekonomi dan Bisnis, 196-204.

Tjiptono, F. A, Diana, ( 2001 ), Total Quality management, Yogyakarta, CV Andi Offset

Bandu, M. Yunus. (2013). Pengaruh Kualitas Pelayanan Terhadap Kepuasan Pelanggan pada PT. PLN (Persero) Rayon Makassar Barat. Skripsi. Fakultas Ilmu Sosial dan Ilmu Politik. Universitas Hasanuddin. Makassar.

Kothler Philip, (2008),Manajemen Pemasaran edisi 13 jilid 1,Airlangga

Kothler Philip, ( 2008 ), ManajemenPemasaran edisi 13 jilid 2, Airlangga.

Naibaho, K. (2007). Perpustakaan sebagai salah satu indikator utama dalam mendukung universitas bertaraf internasional. Buletin Perpustakaan Universitas Airlangga, 2(1), 8-17.

Rofiah, C., \& Wahyuni, D. (2017). Kualitas Pelayanan Dan Pengaruhnya Terhadap Loyalitas Pelanggan Yang Di Mediasi Oleh Kepuasan Di Bank Muamalat Jombang. Eksis: Jurnal Riset Ekonomi dan Bisnis, 12(1 Apr).

Supranto, (2011), pengukuran tingkat kepuasan pelanggan untuk menaikan pangsa pasar, Jakarta Rineka Cipta.

Yamit, Z. (2001). Manajemen kualitas produk dan jasa. Yogyakarta: Ekonisia.

Zeithami, valarei A., Mary jo Bitner, 2004, Service Marketing: Integrating Customer Focus Across The fim 3td., Mc Graw Hill., New Yorker 